\title{
NUTRITIONAL ASPECTS OF NILE TILAPIA (Oreochromis niloticus) SILAGE ${ }^{1}$
}

\author{
Lia FERRAZ DE ARRUDA², Ricardo BORGHESI ${ }^{2}$, Aelson BRUM ${ }^{2}$, \\ Marisa REGITANO D’ARCE ${ }^{3}$, Marília OETTERER ${ }^{3, *}$
}

\section{SUMMARY}

One third of the world's fishing produce is not directly used for human consumption. Instead, it is used for making animal food or is wasted as residue. It would be ideal to use the raw material thoroughly and to recover by-products, preventing the generation of residues. With the objectives of increasing the income and the production of the industry, as well as minimizing environmental and health problems from fish residue, chemical silage from Tilapia (Oreochromis niloticus) processing residues was developed after homogenization and acidification of the biomass with $3 \%$ formic acid: propionic, $1: 1$, addition of antioxidant BHT and maintenance of $\mathrm{pH}$ at approximately 4.0. Analyses to determine the moisture, protein, lipids and ash were carried out. The amino acids were examined in an auto analyzer after acid hydrolysis, except for the tryptophan which was determined through colorimetry. The tilapia silage presented contents that were similar to or higher than the FAO standards for all essential amino acids, except for the tryptophan. The highest values found were for glutamic acid, lysine and leucine. The results indicate a potential use of the silage prepared from the Nile tilapia processing residue as a protein source in the manufacturing of fish food.

Keywords: amino acids, fish residue, by-products.

\section{RESUMO}

ASPECTOS NUTRICIONAIS DA SILAGEM DE TILÁPIA-DO-NILO (Oreochromis niloticus). Um terço da captura mundial de pescado não é empregada para o consumo direto na alimentação humana, segue para elaboração de rações ou é desperdiçada como resíduo. O ideal seria utilizar a matéria-prima em toda a sua extensão e recuperar os subprodutos, evitando a própria formação do resíduo. Com os objetivos de aumentar a receita e a eficiência de produção da indústria e, conseqüentemente, minimizar os problemas ambientais e de sanidade, provenientes do resíduo de pescado, procedeu-se à elaboração da silagem química do resíduo de beneficiamento de Tilápia-do-Nilo (Oreocrhromis niloticus) após homogeneização e acidificação da biomassa com 3\% de ácido fórmico: propiônico, 1:1, adição de antioxidante BHT e manutenção do pH ao redor de 4,0. Foram realizadas análises para determinação da umidade, proteína, lipídios e cinza. Os aminoácidos foram examinados em auto-analisador após hidrólise ácida, à exceção do triptofano determinado por colorimetria. A silagem de tilápia apresentou valores semelhantes ou superiores ao padrão da FAO para todos os aminoácidos essenciais, exceto para o triptofano. Os valores mais elevados encontrados foram para o ácido glutâmico, leucina e lisina. Os resultados indicam a utilização potencial da silagem, preparada a partir do resíduo de processamento da Tilápia-do-Nilo, como fonte protéica na formulação de ração para peixes, uma vez que esta apresentou teores maiores para todos os aminoácidos contidos na farinha de peixe, com exceção do triptofano.

Palavras-chave: aminoácidos, resíduo de pescado, subprodutos.

\section{1 - INTRODUCTION}

According to the Food and Agriculture Organization [12], the world fish production in 2000 was 130.4 million tons of fish, out of which 94.8 million tons were from fishing and 35.6 million tons correspond to aquaculture production.

Sixty percent of the fish captured worldwide are used in the fresh fish market or processed as frozen, canned or cured foods, causing a considerable amount of waste material. The volume of waste produced by processing plants is calculated to be approximately $50 \%$ of the total processed fish. To that, we can add a considerable amount of fishing produce that is considered inadequate for human consumption due to its low commercial value, as well as the amounts

\footnotetext{
${ }^{1}$ Recebido para publicação em 7/6/2005. Aceito para publicação em 20/10/2006 (001539)

${ }^{2}$ Food Science and Technology at the Agri-food industry,

Food and Nutrition Dept. (USP/ESALQ)

${ }^{3}$ Foods and Nutrition Department (USP/ESALQ),

"Luiz de Queiroz" College of Agriculture, University of São Paulo, Av. Pádua dias, 11, C. P. 9, CEP 13418900, Piracicaba (SP), Brasil, E-mail:moettere@esalq.usp.br

* A quem a correspondência deve ser enviada
}

discarded for being refused by Federal/State Inspections in fresh commercialization markets [25].

Approximately $50 \%$ of the world fish production has become waste material, which means a significant amount of 65.2 million metric tons of fish waste [13].

The growth of aquaculture associated to improvements in increasingly intensive cultivation practices has intensified the demand for high quality foods [7] which allow a formulation of highly nutritive, economically viable and ecologically correct diets.

As in any zoo technical culture, feeding is accountable for a high percentage of the operational cost in fish farming, reaching indices of 40 to $60 \%$. Protein ingredients contribute to the largest part of this cost [2].

Due to its high biological value, amino acids and fatty acid balance, high levels of calcium and phosphor, as well as liposoluble and hydrosoluble vitamins, fish meal is regarded as the main source of dietetic protein used in fish feed, with a high performance [27].

Various research on cost and nutritional aspects have been carried out in order to find an adequate substitute for fish meal [3, 23, 31]. 
The present work has attempted to use fish waste to develop acid silage of the Nile tilapia (Oreochromis niloticus) with the objectives of increasing the income and the production of the industry, as well as minimizing environmental and health problems from fish residue. Fish silage has a high potential of usage in aquaculture due to the similarity of this protein source with the raw material, especially amino acids, such as lysine, methionine, and cystine [4, 9, 26, 35].

Currently, tilapias are among the most widely produced fish species around the world, with an annual production of $1,265,780$ metric tons in 2000 [11]. Tilapia meat has good organoleptic characteristics, with a fillet yield of up to $33 \%$ [33]. With the increase in the amount of tilapia (Oreochromis niloticus) processing units, the waste from this activity has become a problem.

The use of this waste material, which is rich in protein and lipids, is very important, as it not only decreases costs and improves production efficiency, but also minimizes problems with environmental pollution which are created by the lack of an adequate destination for this material [6, 8, 18].

\section{2 - MATERIALS AND METHODS}

The raw material for the fish chemical silage was made up of Nile tilapia (Oreochromis niloticus) waste from commercial farms in the area of Piracicaba, SP, Brazil.

The tilapia waste used resulted from the filleting of 40 tilapia samples (total weight of $21 \mathrm{~kg}$ and average weight per fish of $500 \mathrm{~g}$ ) carried out in the laboratories of the Food Processing Sector of the Agroindustry, Food and Nutrition Department of ESALQ/USP, as recommended by OETTERER [21]. The wasted material recovered to develop the silage weighed $15 \mathrm{~kg}$ and was made up of $7.7 \mathrm{~kg}$ of heads, $2.5 \mathrm{~kg}$ of fins, $1.5 \mathrm{~kg}$ of viscera, and $3.5 \mathrm{~kg}$ of vertebral spine, skin and tissues.

The raw material was fragmented in an electric grinder; model ML-4.0/Weg- $\mu$ line. Afterwards, it was homogenized, weighed and uniformly distributed into 3 hard plastic containers. Then, we added BHT antioxidant, dissolved it in ethylic alcohol at the concentration of $0.02 \mathrm{~g} \mathrm{~kg}^{-1}$, and the acid mixture (propionic and formic at the ratio of $1: 1$ ), at the proportion of $3 \%$ of acid solution for the total waste mass. Both solutions were manually added to the homogenized material and constantly mixed, resulting in the chemical tilapia silage, in which a daily $\mathrm{pH}$ control was carried out in order to maintain it at approximately 4.0. The silage was kept at room temperature $\left(27^{\circ} \mathrm{C} \pm 1^{\circ} \mathrm{C}\right)$ for $72 \mathrm{~h}$, and then, was submitted to centesimal composition analysis. All determinations were carried out in triplicates in accordance with A.O.A.C [1].

A sensory analysis of appearance parameters, such as mass formation, color, and odor was also performed, observing the behavior of the biomass for $72 \mathrm{~h}$ after developing and adding acids

The amino acids were determined and were analyzed by liquid chromatography in cationic exchange resin columns and post-column derivation with ninhydrin and an autoanalyzer. For the amino acids count, the samples were hydrolyzed with $\mathrm{HCl} 6 \mathrm{~N}$ for $22 \mathrm{~h}$ at $110^{\circ} \mathrm{C}$ according to the method described by MOORE \& STEIN [19].

Tryptophan was determined after the enzymatic hydrolysis with Pronase at $40{ }^{\circ} \mathrm{C}$ for $24 \mathrm{~h}$, followed by a colometric reaction with 4-Dimethyl-Amino-Benzaldehyde (DAB) in sulfuric acid $21.2 \mathrm{~N}$ and read at $590 \mathrm{~nm}$. The content of tryptophan was calculated with Spies [30].

The chemical score of the silage was determined in accordance with SGARBIERI [29], by the ratio between the content of each essential amino acid and the corresponding amino acid content of a standard protein. In this research, the acid silage score was calculated by using FAO's standard [10] as protein sources.

\section{3 - RESULTS AND DISCUSSION}

From the experiment carried out, we may affirm that, as explained by OTTATI et al. [22], the process for silage production was simple, practical and economical, as there was no need for expensive equipment and procedures as those used in the production of fish meal.

Even though various research on the production and use of silage has already been carried out, unlike in other countries, silage has not been commercially produced by Brazilian industries, and the lack of a steady quality supply of silage is the reason why it is not commonly used.

In the visual examination of silages, we observed that the liquefaction of the homogenous mass began between the $18^{\text {th }}$ and the $24^{\text {th }} \mathrm{h}$ and increased until the end of the experiment $(72 \mathrm{~h})$, resulting in a brownish liquid-pasty product with acid $\mathrm{pH}$ (lower than 4.12) and an aroma, as previously described by MORALLES-ULLOA \& OETTERER [20]. This aspect is due to the continuous protein hydrolysis that occurs in the silage because of the action of proteolytic enzymes that are either naturally present in fish, especially in the viscera, or are added [14].

The acid pH (less than 4.12) and the bactericide action of propionic acid guaranteed the quality of the acid silage during the experimental period [24].

Table 1 shows the macro components of the chemical tilapia fish silage.

The result obtained for the crude protein content of the acid silage is slightly higher than that presented by HERAS et al. [15] - $57.75 \mathrm{~g} \mathrm{~kg}^{-1}$ - and by HUSSAIN \& OFFER [16] - $56.50 \mathrm{~g} \mathrm{~kg}^{-1}$ - for acid silage. However, it differs from the results obtained by JOHNSON et al. [17] $37.10 \mathrm{~g} \mathrm{~kg}^{-1}$.

The macro components found by VIDOTTI [36] for the chemical tilapia fish silage produced also from filleting waste as $31.38 \mathrm{~g} \mathrm{~kg}^{-1}$ of dry matter were as follows: $68.62 \mathrm{~g} \mathrm{~kg}^{-1}$ of moisture, $5.13 \mathrm{~g} \mathrm{~kg}^{-1}$ of ash, $13.49 \mathrm{~g} \mathrm{~kg}^{-1}$ of crude protein and $10.85 \mathrm{~g} \mathrm{~kg}^{-1}$ of ether extract.

SALES [28] affirms that the residue can change according to the sampling period (season), the skills of the 
employees of the industry, as well as technical aspects of tilapia production. This affirmation can be an explanation concerning differences in the values found in the chemical analyses carried out for silage made in this work and the result of other research to characterize silages produced with the same kind of raw material by VIDOTTI [36].

TABLE 1 - Centesimal composition of the tilapia fish silage.

\begin{tabular}{lcc}
\hline Components $^{*}$ & Wet matter $\left(\mathbf{g} \mathbf{1 0 0} \mathbf{~ g}^{-1}\right)$ & Dry matter $\left(\mathbf{g ~ 1 0 0 ~} \mathbf{~ g}^{-1}\right)$ \\
\hline Dry matter & - & $21.68 \pm 0.83$ \\
Moisture & $78.32 \pm 0.81^{* *}$ & - \\
Ash & $4.17 \pm 0.23$ & $19.23 \pm 0.24$ \\
Crude protein & $12.85 \pm 0.65$ & $59.27 \pm 0.64$ \\
Ether extract & $3.89 \pm 0.35$ & $18.40 \pm 0.33$ \\
\hline
\end{tabular}

*average of 3 replications; and ${ }^{* *}$ standard deviation of the average.

Table 2 shows the values of the centesimal composition for fish silage produced from different raw materials.

Comparing the results found in this research and shown in Table 1 to the values in Table 2, it can be said that the silage composition is directly related to its source material. Therefore, for possible industrial use as a protein source in the manufacturing of food, standardization and the indication of the composition of the silage produced are necessary.

This demand can be facilitated in the future with the increase in the participation of intensive aquaculture in fish production [35], resulting in a more homogenous product both in terms of its composition, due to the standardization of feeding with the use of well balanced food, and in terms of the fish size, facilitating the adjustment of the equipment by industries. In this research, the introduction of the antioxidant helped its standardization as well as handling after catching, as suggested by OETTERER [21].

TABLE 2 - Chemical composition of different types of acid fish silage.

\begin{tabular}{llccl}
\hline Substratum & \multicolumn{1}{c}{ Origin/species } & Protein & Ether extract & Ash \\
\hline By-catch & Thailand & 58.1 & 4.2 & 30 \\
& England & 66.5 & 16.6 & 11.7 \\
& Cuba & 52.6 & 10.4 & 11.9 \\
\hline Waste & Atlantic herring & 48.3 & 28.2 & 125 \\
& (Clupea harengus) & & & \\
& Tuna (Tunnus spp.) & 69.9 & 12.2 & 10.5 \\
& Cod (Gadus morhua) & 68.1 & 2.1 & 19 \\
\hline
\end{tabular}

Note: values shown in $\mathrm{g} 100 \mathrm{~g}^{-1}$ of dry matter; and Source: FAO [11].

Table 3 shows the contents of amino acids of the tilapia silage produced.

Glutamic acid, aspartic acid, glycine, alanine, leucine and lysine were the amino acids found in highest concentrations in the silage developed in this research (Table 3), confirming the findings of MORALES-ULLOA \& OETTERER [20], VIDOTTI [36] and VIDOTTI et al. [37].
TABLE 3 - Amino acids in the chemical tilapia silage compared to FAO's standard in $\mathrm{g} 100 \mathrm{~g}^{-1}$ of protein.

\begin{tabular}{lcc}
\hline \multicolumn{1}{c}{ Amino acids * } & g $\mathbf{1 0 0} \mathbf{~ g}^{-1}$ & (FAO) $\mathbf{~} \mathbf{~ 1 0 0 ~} \mathbf{~}^{-1}$ \\
\hline Aspartic acid & 10.92 & - \\
Threonine & 4.72 & 4.00 \\
Serine & 3.66 & - \\
Glutamic acid & 12.02 & - \\
Proline & 5.60 & - \\
Glycine & 8.82 & - \\
Alanine & 7.52 & - \\
Cystine & 1.54 & - \\
Valine & 5.40 & 5.00 \\
Methionine & 4.34 & 3.50 \\
Isoleucine & 6.46 & 4.00 \\
Leucine & 7.00 & 7.00 \\
Phenylalanine + Tyrosine & 6.70 & 6.00 \\
Lysine & 6.66 & 5.50 \\
Histidine & 2.80 & - \\
Arginine & 5.80 & - \\
Tryptophan & 0.72 & 1.00 \\
*Average of 3 replicates; and ${ }^{* *}$ Source: FAO $[10]$ &
\end{tabular}

As recommended by STRON \& EGGUM [32], the lysine, cystine and methionine contents must be especially observed in the elaboration of fish feed. The silage produced in this research did not lack any of these amino acids.

The tilapia silage presented values that were similar or above FAO's standards [10] for all essential amino acids, except for tryptophan, compatible with STRON \& EGGUM [32]. According to FAGBENRO \& BELLO-OLUSOJI [9], tryptophan is unstable in acid conditions.

The chemical score obtained in this research, in accordance with the methodology proposed by SGARBIERI [29], is similar to that found by VIDOTTI [36]. The critical (limiting) amino acid was tryptophan, as it corresponds to $72 \%$ of the standard content. However, we must regard critical amino acids as those which are $30 \%$ under the minimum requirements for fish. Thus, according to the limits discussed by TACON [34], the fish silage produced is not deficient in any essential amino acid.

Table 4 shows the essential amino acids present in the tilapia silage and the essential amino acids in the fish meal from a Chilean commercial brand used by PORTZ [20] to compare alternative protein sources. The content of essential amino acids in the tilapia silage was higher than in the fish meal.

The use of high temperatures during the manufacturing process of fish meal potentially provokes the denaturation of amino acids. The production of silage does not cause the immediate loss of amino acids, because it does not involve excessive temperatures. However, according to MORALLES-ULLOA \& OETTERER [20], after about a week, silage begins to go through quality loss in the protein fraction. Due to this characteristic, the use of the silage as a protein source is recommended to take place as soon as possible, for if the storage is long, it would become a critical nutritional point. 
TABLE 4 - Essential amino acids in the chemical tilapia silage compared to those found in fish meal.

\begin{tabular}{lcc}
\hline \multicolumn{1}{c}{ Aminoacids } & Silage $\left.\mathbf{( g ~} \mathbf{1 0 0} \mathbf{~}^{-1}\right)$ & Fish meal $\left.\mathbf{( g ~} \mathbf{1 0 0} \mathbf{~ g}^{-1}\right)$ \\
\hline Tryptophan & 0.72 & 0.42 \\
Lysine & 6.66 & 5.79 \\
Histidine & 2.80 & 1.38 \\
Arginine & 5.80 & 4.39 \\
Threonine & 4.72 & 2.93 \\
Valine & 5.40 & 3.93 \\
Methionine & 4.34 & 1.62 \\
Isoleucine & 6.46 & 3.20 \\
Leucine & 7.00 & 4.81 \\
Phenylalanine + Tyrosine & 6.70 & 6.19 \\
\hline${ }^{* *}$ Soure: Portz & &
\end{tabular}

**Source: Portz [23].

According to MORALLES-ULLOA \& OETTERER [20], fish silage must not be regarded as a competitor for fish meal, but as an alternative for the use of available sources and a possible end for the waste from fish processing.

CYRINO [5] reports that several protein sources available on the market for the formulation of food do not have the same nutritional value or composition of amino acids required by the fish in terms of both quality and quantity. In the produced silage, the composition of amino acids and the concentration of crude protein were adequate (Tables 1, 3, and 4). However, for the estimation of the silage quality to be estimated as a source of protein and to carry out formulations of economical and efficient feed, "in vivo" digestibility surveys are necessary.

\section{4 - CONCLUSIONS}

Acid silage of tilapia waste became pasty and homogenous $24 \mathrm{~h}$ after production at a room temperature of $26-30{ }^{\circ} \mathrm{C}$.

Silage presented $59.27 \%$ of crude protein in the dry matter and all essential amino acids in similar or higher amounts than those required by FAO's standards, except for tryptophan.

The contents of essential amino acids, leucine and

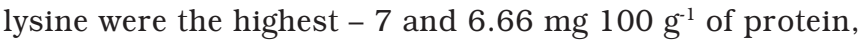
respectively.

The contents of threonine, valine, methionine, isoleucine and lysine were higher than the ones required by FAO's standards.

The results indicate the possible use of silage prepared with wastes from the processing Nile tilapia (Oreochromis niloticus) processing in the formulation of food for fish cultivation.

\section{5 - REFERENCES}

[1] ASSOCIATION OF OFFICIAL ANALYTICAL CHEMISTS. Official methods of analysis. 14 ed. Washington, 1990. $1141 \mathrm{p}$.

[2] CHENG, Z. J.; HARDY, R. W.; USRY, J. L. Effects of lysine supplementation in plant protein-based diets on the performance of rainbow trout (Oncorhynchus mykiss) and apparent digestibility coefficients of nutrients. Aquaculture, v. 215, p. 255-265, 2003.

[3] CHONG, A. S. C.; HASHIM, R.; ALI, A. B. Assessment of dry matter and protein digestibilities of selected raw ingredients by discus fish (Symphysodon aequifasciata) using in vivo and in vitro methods. Aquaculture Nutrition, v. 8, p. 229-238, 2002.

[4] COELlO, N.; BRITO, L.; NONUS, M. Biosynthesis of Llysine by Corynebacterium glutamicum grown on fish silage. Bioresource Technology, v. 73, p. 221-225, 2000.

[5] CYRINO, J. E. P. Condicionamento alimentar e exigências nutricionais de espécies carnívoras: desenvolvimento de uma linha de pesquisa. 2000. 200p. Tese (Livre-Docência) - Escola Superior de Agricultura "Luiz de Queiroz”, Universidade de São Paulo, Piracicaba, 2000.

[6] DAPKEVICIUS, M. L. E.; NOUT, R. M. J.; ROMBOUTS, F.M. et al. Biogenic amine formation and degradation by potential fish silage starter microorganisms. International Journal of Food Microbiology, v. 57, p. 107-114, 2000.

[7] ESPE, M.; LIED, E. Fish silage prepared from different cooked and uncooked raw materials: Chemical changes during storage at different temperatures. Journal of the Science Food and Agriculture, v. 79, p. 327-332, 1999.

[8] ESPÍNDOLA FILHO, A. Aproveitamento do resíduo sólido de peixe, camarão e bivalves como ingrediente de ração para aqüicultura, 1999. 224p. Tese (Doutorado) - Universidade Mackenzie, São Paulo, 1999.

[9] FAGBENRO, O.; BELlO-OLUSOJI, O. A. Preparation, nutrient composition and digestibility of fermented shrimp head silage. Food Chemistry, v. 60, n. 4, p. 489493, 1997.

[10] FAO. Report of joint FAO/WHO/ONU Expert Consulation Technical Report, 1985, Geneve. Energy and protein requeriments. Geneve: FAO/WHO and the United Nations University, 1985. (FAO Series n. 724).

[11] FAO. Feeding pigs in the tropics. In: FAO Animal Production and Health, n.132. Disponível em: http://www. fao.org. Acesso em: 24 Jan. 2003.

[12] FAO. Examen mundial de la pesca y aquacultura: Fisheries Information Sistem. Disponível em: http://www. fao.org. Acesso em: 21 jun. 2004.

[13] FERRAZ DE ARRUDA, L. Aproveitamento do resíduo do beneficiamento para obtenção de silagem e óleo como subprodutos, 2004, 78p. Dissertação (Mestrado) - Escola Superior de Agricultura "Luiz de Queiroz", Universidade de São Paulo, Piracicaba,78p.

[14] HAARD, N. F.; KARIEL, N.; HERZBERG, G. et al. Stabilization of protein and oil fish in silage for use as a ruminant feed supplements. Journal of the Science of Food and Agriculture, v. 36, n. 4, p. 229-241, 1985.

[15] HERAS, H.; MCLEOD, C. A.; ACKMAN, R. G. Atlantic dogfish silage vs. herring silage in diets for Atlantic salmon (Salmo salar): growth and sensory evaluation of fillets. Aquaculture, v. 125, p. 93-103, 1994. 
[16] HUSSAIN, R. A. K.; OFFER, N. W. Effect of folmaldehyde treatment on the degradation of acid-preserved fish silage protein in vitro. Animal Feed Science and Technology, v. 16, p. 297-304, 1987.

[17] JOHNSON, R. J.; BROWN, N.; EASON, P. et al. The nutritional quality of two types of fish silage for broiler chickens. Journal of the Science of Food and Agriculture, v. 36, n. 11, p. 1051-1056, 1985.

[18] MINISTÉRIO DA AGRICULTURA, PECUÁRIA E ABASTECIMENTO. Convênio MAPA/Universidade do Vale do Itajaí. Relatório final de ações prioritárias ao desenvolvimento da Pesca e Aquicultura no Sul do Brasil, Itajaí, 2000. 130p. Relatório.

[19] MOORE, I; STEIN, W. H. Chromatographic determination of amino acids by use of automatic recording equipaments. Methods in Enzymology, v. 6, p. 919$931,1963$.

[20] MORALES-ULlOA, D. F.; OETTERER, M. Composição em aminoácidos de silagens químicas, biológicas e enzimáticas preparadas com resíduos de sardinha. Ciência e Tecnologia de Alimentos, v. 17, n. 3, p. 252-258, 1997.

[21] OETTERER, M. Industrialização do pescado cultivado. 1 ed. Guaíba: Agropecuária, 2002. 200p.

[22] OTtATI, M.; GUTIERREZ, M.; BEllo, R. Estudio sobre la elaboración de ensilado microbiano a partir de pescado proveniente de especies subutilizadas. Archivos Latinoamericanos de Nutrición, v. 4, n. 3, p. 408-425, 1990.

[23] PORTZ, L. Utilização de diferentes fontes protéicas em dietas formuladas pelo conceito de proteína ideal para o "black bass" (Micropterus salmoides), 2001. 111p. Tese (Doutorado) - Escola Superior de Agricultura "Luiz de Queiroz", Universidade de São Paulo, Piracicaba, 2001.

[24] RAA, J.; GILDBERG, A. Fish silage: a review. Journal of the Food Science and Nutrition, v. 61 , n. 4 , p. 383419, 1982.

[25] REBECA, B. D.; PENA - VERA, M. T.; DIAS - CASTANEDA, M. Production of fish protein hydrolisates with bacterial proteases; yield and nutritional value. Journal of Food Science, v. 56, n. 2, p. 309-314, 1991.

[26] RISTIC, M. D.; FILIPOVIC, S. S.; SAKAC, M. L. J. Liquid protein feedstuffs from freshwater fish by-products as a component of animal feed. Romanian Biotechnological Letters, v. 7, n. 3, p. 729-736, 2002.

[27] SALES, J.; BRITZ, P. J. Apparent and true availability of amino acids from common feed ingredients for South African abalone (Haliotis midae L.). Aquaculture Nutrition, v. 9, p. 55-64, 2003.
[28] SALES, R. O. Processamento, caracterização química e avaliação nutricional da silagem da despesca da tilápia do Nilo (Oreochromis niloticus) em dietas experimentais com ratos, 1995. 174p. Tese (Doutorado) - Faculdade de Engenharia de Alimentos, Universidade Estadual de Campinas, Campinas, 1995.

[29] SGARBIERI, V. C. Alimentação e nutrição: fator de saúde e desenvolvimento. 2 ed. Campinas: UNICAMP, 1987. 387p.

[30] SPIES, J. R. Determination of tryptophan in proteins. Analytical Chemistry, v. 39, p. 1412-1415, 1967.

[31] STONE, D. A. J.; ALLAN, G. L.; PARKINSON, S.; ROWLAND, S. J. Replacement of fish meal in diets for Australian silver perch, Bidyanus bidyanus, IIIDigestibility and growth using meat meal products. Aquaculture, v. 186, p. 311-326, 2000.

[32] STRON, T.; EGGUM, R.W. Nutritional value of fish viscera silage. Journal of the Science of Food and Agriculture, v. 32, p. 115-120, 1981.

[33] TACHIBANA, L. Desempenho inicial e digestibilidade aparente de nutrientes de diferentes linhagens de tilápia do Nilo (Oreochromis niloticus), 2002. 46p. Dissertação (Mestrado) - Centro de Aqüicultura, Universidade Estadual Paulista "Júlio de Mesquita Filho" Jaboticabal, 2002.

[34] TACON, A. G. J. Feed ingredients for carnivorous fish species: alternatives to fish meal and other fisheries resources. In: FAO Fisheries Circular, 881. Roma: FAO, 1994.

[35] VALENTI, W. C. Aquaculture for sustainable development. In: VALENTI, W. C.; POLI, C. R.; PEREIRA, J. A.; BORGHETTI, J. R. Aqüicultura no Brasil. Brasília: CNPq/Mistério da Ciência e Tecnologia, 2000. p. 17-24.

[36] VIDOTTI, R. M. Produção e utilização de silagens de peixe na nutrição do pacu (Piaractus mesopotamicus), 2001.65p. Tese (Doutorado) - Centro de Aqüicultura, Universidade Estadual Paulista "Júlio de Mesquita Filho", Jaboticabal, 2001.

[37] VIDOTTI, R. M.; VIEGAS, E. M. M.; CARNEIRO, D. J. Amino acid composition of processed fish silage using different raw materials. Animal Feed Science and Technology, v. 105, p. 199-204, 2003.

\section{6 - ACKNOWLEDGMENT}

We would like to thank the Foundation for Research Support from the State of São Paulo (FAPESP) for funding this research. 